\title{
OASIAN CITIES: A TOURIST HERITAGE THREATENED BY THE INVASION OF URBAN EXPANSION, CASE OF THE OASIS OF BOUSSAADA, ALGERIA
}

\author{
Hadjira BERBACHE* \\ Houari Boumediene Sciences and Technology University, Departement of Geography \\ and Territorial Planning, 16000, Algiers, Algeria, e-mail: berbachehadjira@gmail.com \\ Makhloufi HADJAB \\ Mohamed Boudiaf University, Institute of Management of Urban Technologies, \\ 28000, M'sila, Algeria, e-mail: hadjab.makhloufi@univ-msila.dz
}

\begin{abstract}
Citation: Berbache, H., \& Hadjab, M. (2020). OASIAN CITIES: A TOURIST HERITAGE THREATENED BY THE INVASION OF URBAN EXPANSION, CASE OF THE OASIS OF BOUSSAADA, ALGERIA. GeoJournal of Tourism and Geosites, $31(3)$, $1119-1125$. https://doi.org/10.30892/gtg.31325-548
\end{abstract}

\begin{abstract}
The Oasis of Boussaâda is a natural, architectural and cultural heritage, which made it a destination for investors in the field of tourism. Since the $1980 \mathrm{~s}$, there has been a random expansion of uncontrolled structures within palm groves, which have become threatened with extinction, because of the lack of urban space and the increasing demographic growth. In this context, the present study dealt with the discussion and analysis of the impact of urban expansion on Boussaâda Oasis, which received large numbers of immigrants from most of the country during the period 1987-1998. These factors have resulted in increasing population growth and rapid urban expansion; but most of the time, this expansion was irrational and not subject to urban legal constraints because of the weak mechanisms for applying laws and influence of government planning and policy which has had impacts on the oasis. Within this perspective, the research aims to follow the stages of urban expansion of the oasis of Boussaâda, showing the expansion reasons and the consequences on the expense of the Oasis.
\end{abstract}

Key words: Oasis of Boussaâda, Algeria, Oasian Cities, Tourist Heritage, Urban Expansion, Population Growth, government planning and policy

$* * * * * *$

\section{INTRDUCTION}

The oasis is a specific landscape that exists with deserts in arid regions (Jia et al., 2004). It is the basis of human settlement and economic development (Liu et al., 2018) because of the availability of fertile soil, fresh groundwater and surface runoff from nearby mountains (Luo et al., 2008; Zhou et al., 2017). And it is one of the characteristic of ecological landscapes and the primary space for human life and agricultural production in the arid region (Wang et al., 2010). The urban expansion on one hand is an indicator of economic, social and political growth whereas, on the other hand it is at the cost of forests, agriculture lands, orchards and greenery of the city (Torrens and Alberti, 2000; Barnes et al., 2001, Ahmad and Laxmi, 2016). The encroachment of parks and reserves is Fincreasingly becoming a problem, especially with the rapid urbanization (Adjewodah and Beier, 2004; Eshun and Tichaawa, 2020), which may result in a demand for the productive use of land, such as for housing, food production, public infrastructure, and other uses (Xie et al., 2014). The absence of healthy planning in the cities also helps to expand construction on the expense of agricultural land, in addition to the role of the behavioral factor represented in the desire of the population to reside in the suburbs outside the cities (Wahdan, 2013). Algeria, like the other countries in the world, has been living in a similar situation since the independence, despite the successive policies of organizing its field; and similar to the Algerian oasis cities, especially the steppes, the city of Boussaâda, with an oasis-tourist character, it is considered one of the interior regions, rich in natural and human tourism potential which have not been equipped with a tourism development strategy (Kherrour et al., 2018).

Plus it should be noted that the city is enduring a big population pressure, this environment that contains all this population has grown and developed because of the natural increase and the large influx of migratory numbers witnessed by the region in different periods of time (Berbache, 2008); the city attracted a total of 6348 arrivals during the period (1987-1998) (ONS, 1987-1998) especially from neighboring municipalities due to the uneven distribution of the development projects. This great population pressure resulted in an irrational expansion of the urban environment through the extension at the expense of the palm groves (Lettre Wallonie-Bruxelles à Alger $n^{\circ} 1,2008-2010$ ), the rapid expansion of oases is always accompanied by change of hydrological processes, soil and ecosystem stability (Maeda et al., 2011; Nian et al., 2014; Bai et al., 2014; Zuo et al., 2014; Zhou et al., 2017). Excessive expansion of oases may increase the high risk of environmental degradation in arid areas (Qi et al., 2007), and the result is the deterioration of the oasis. All this has negatively affected the beauty and reputation of the city, as its oasis-tourist character requires it to be a homogenous, functional and aesthetically pleasing area. As it is known, there is strong relation between environmental condition and touristic perspectives (Ilieș et al., 2017; Azhayev et al., 2020).

Therefore, the study of urban expansion on the oasian cities and its impacts on the stability of oases are essential for sustainable development in the arid regions However, there were few researches to analyze urban expansion and its impacts on the oasis of Boussaâda. That is exactly what motivated our approach to study the impact of urban expansion on the oasis of Boussaâda.

\section{STUDY OBJECTIVE}

The main objectives of this study are to (1) detect the stages and the trends of urban expansion in the oasis of Boussaâda from 1972 to 2017; (2) identify the expansion driving factors and the consequences on the expense of the Oasis; (3) discuss feasible recommendations for the sustainability of the Boussaâda oasis. Through how to restore the beauty of the city and its tourist reputation, and make it more attractive.

\section{STUDY AREA}

Boussaâda is the closest oasis to Algiers, just about 250 kilometers south of it. It is one of the municipality's of the province of M'sila and also one of its centers in the middle of the province. The city of Boussaâda has an area of $248 \mathrm{~km}^{2}$. It is located at $35^{\circ} 12^{\prime \prime}-35^{0} 15^{\prime \prime} \mathrm{N}$

\footnotetext{
* Corresponding author
} 
latitude and $4^{0} 9^{\prime \prime}-4^{0} 12$ " E longitude (Figure 1), this city has a population of 157476 inhabitants and a population density estimated at 635 $\mathrm{inh} / \mathrm{km}^{2}$ (DPSB, 2017). It has an important strategic location in terms of its presence on the axis of the national roads. It also has a diversity of natural, cultural and even tourist attractions beyond state borders.

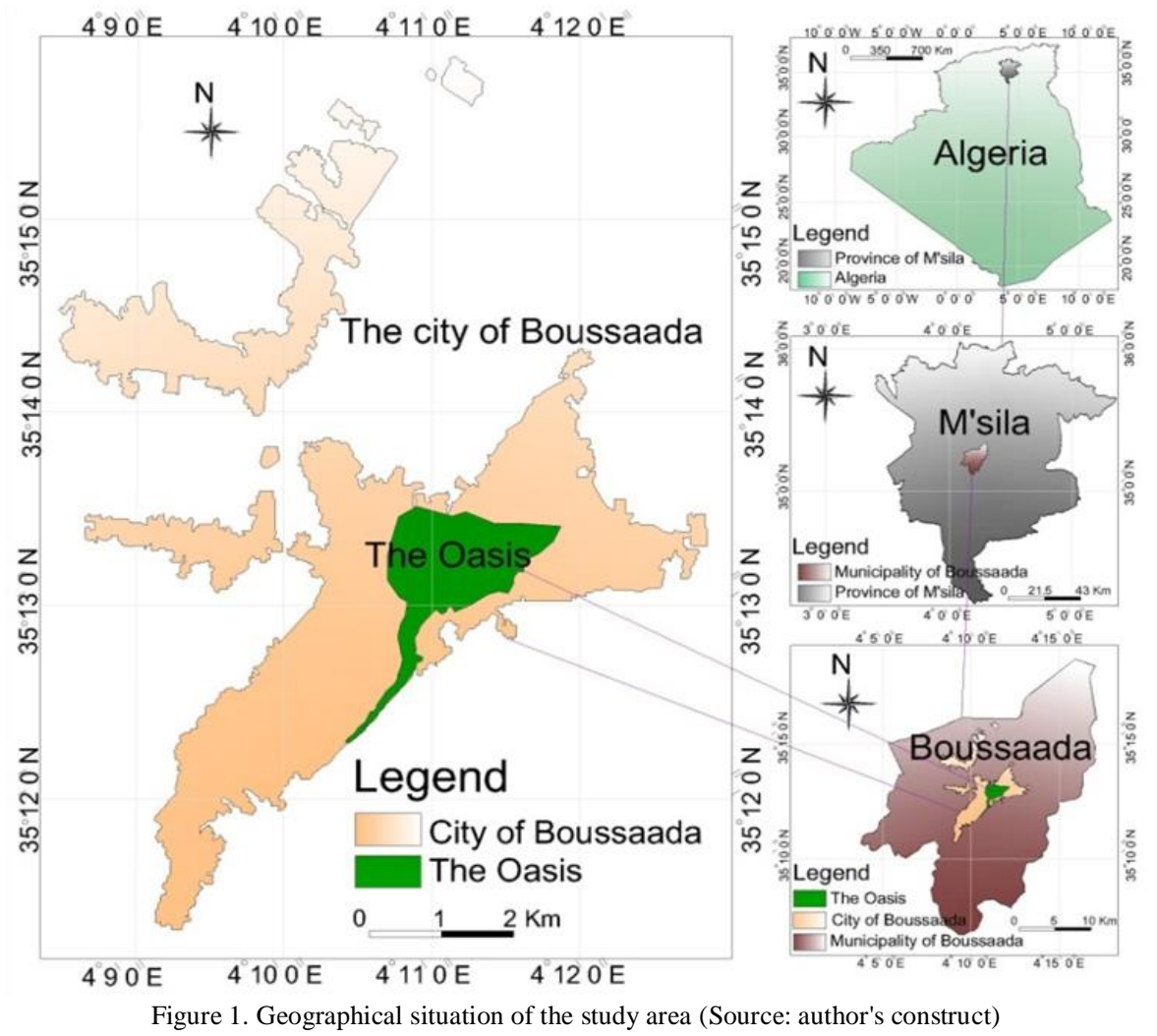

\section{MATERIALS AND METHODOLOGY}

In this study, we follow the historical approach in studying the stages of urban expansion of Boussaâda city, descriptive approach in the study and diagnosis of the current urban reality of the city, the analytical approach in the analysis and evaluation of land use change and the factors influencing it and the impact of urban expansion on the oasis by the increasing number of buildings and the lack of area of palm orchards, based on the information and data, both quantitatively and qualitatively from different sources. Aerial photographs and maps were used to explain the pattern of expansion and its trends in the city of Boussaâda. The most important tools used in this study were:

- AutoCAD program to draw some maps related to the location of the study area.

- The Geographic information systems technology ArcGIS and its various programs and use them in the analysis process.

- Remote sensing programs such as the ErDAS program in the processing of aerial photographs and we used recent images of $2004,2017$.

- Photography.

- The continuous field observations throughout the research period.

- Our focus was basically on the aerial photos of the area from about 16 years (since 2004), and the presentment of the agricul tural areas that existed until recently, as well as the analysis of these images to show the urban expansion over the oasis.

\section{The urban expansion of the oasis of Boussaâda}

The oasis of Boussaâda whose Arabic name means "city of happiness", it is a meeting point between the north, south, east and west, making it an area of attraction since ancient times. It was an important trade center and a center for commercial convoys. The city dates back to 1492, when old mosque was established (The Palm Mosque) (Nacib, 1986). Near the Oasis, and then the buildings and residential neighborhoods were built around it, interspersed with squares and narrow and twisting streets, overlooking low and compact housing, and this is what He produced a compact and dense urban fabric, which form in total the k'sar or Medina of Boussaâda (the old city now), where the name of the oasian cities was called the "k'sar", when the inhabitants lived in the k'sar and work in the oasis (Figure 2).

The establishment of this site was based on the presence of fundamental factors in the old urban pattern of the Arab-Islamic cities, such that "the palaces were built over the highlands or on the hills and this in order to have more exposure to the sun in winter and protection from the wind and floods in addition to the difficulty of invasion" (Nacib, 1986).

When the French colonialism entered the city in 1849, Boussaâda had a population of 4,500, comprising 600 houses, 500 orchards and 25,000 palm trees. The area of the oasis was then estimated at $2 / 3$ of the city's area, and in 1870 a general plan for the oasis on the $1 / 4000$ scale was created, with the city and its surrounding orchards covering 272 hectares (Kouran, 2015). The orchards were small squares that extended all along the valley (Figure 3), (Nacib, 1986), where the residents of the oasis depended on the sources coming from the vall ey of Boussaâda, which in turn passed through the Ferrero Mill built by the Italian Antoine Ferrero near the waterfall because it was running water strongly.

In 1860, the colonialism established some neighborhoods adjacent to the palace "k'sar" to accommodate the colonists, and it completed some administrative and service facilities, in the same period, the urban fabric defined the birth of new neighborhoods from the eastern side, along the valley of Boussaâda and near the oasis. These expansions can be considered as the basis for architectural forms that are not subject to law or to an engineering system except to sweep areas of land (Berbache, 2005).

Due to the importance of the tourist area, many hotels were established such as the hotel of "Kerdada", the Beau-Séjour", the "Oasis Hotel", and the "Caid" hotel in 1929, the activity of some of these hotels continues today, and the first and highest goal is tourism. 
After the independence, exactly from 1962 to 2017, the city of Boussaâda expanded in all directions with the emergence of legal and illegal neighborhoods and the construction on private properties and public lands. Here, we can refer to three images of the reconstruction identified by the city: residential retail areas, illegal construction and the new urban area (Berbache, 2005). so the number of housing units increased from 4819 housing units in 1966 to 25,122 housing units in 2008 (ONS, 1966-2008), to reach to 30915 housing units in 2017 (DPSB, 2017).

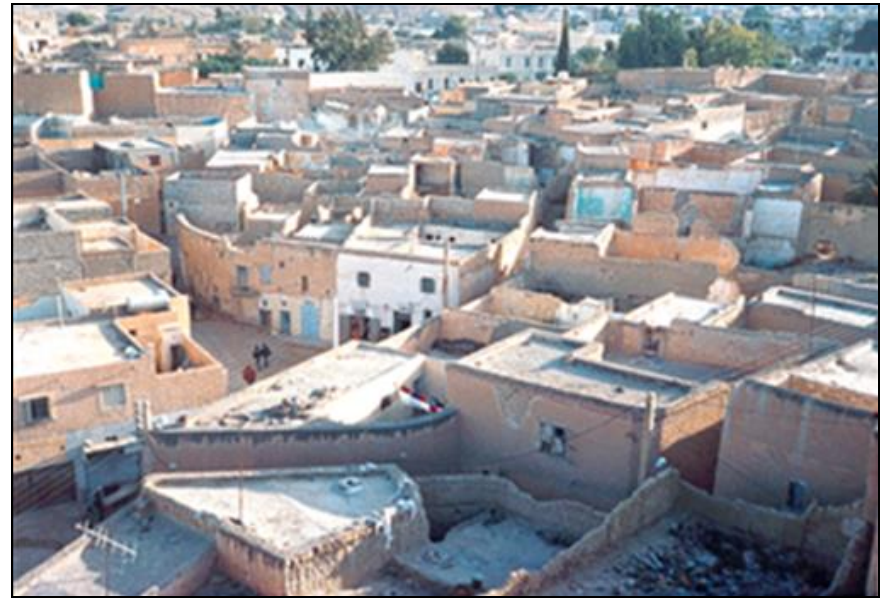

Figure 2. A general view of the k'sar of Boussaâda

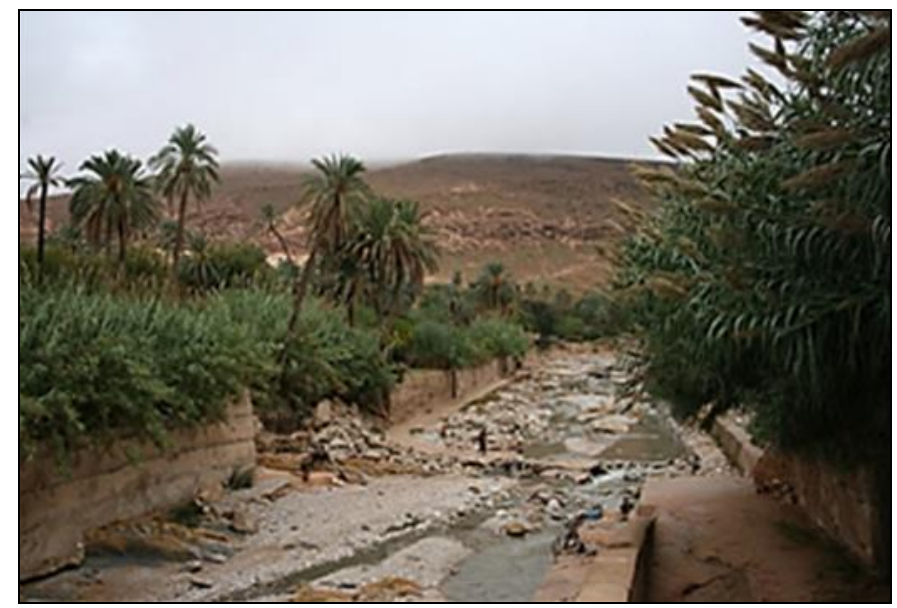

Figure 3. The palm groves (the oasis) next to the valley of Boussaâda

Urban expansion trends of the oasis of Boussaâda

During the period 1962-1972, great stagnations were recorded in the construction and housing sectors in the wake of independence.

From 1972 to 2001, the city of Boussaâda witnessed rapid urban dynamics: 5 districts in 1972, 10 districts in 1983 and more than twenty in 2001, and found births in unstable marginal areas, harboring more than $60 \%$ of the city's population (Salmon et al., 2009), as the area of the built framework evolved from $1.21 \mathrm{~km}^{2}$ in 1972 to $6.62 \mathrm{~km}^{2}$ in 2001 (RBA, 2001). Its urban texture has speeded in a remarkable and poorly controlled manner: first, towards the southwest, by fabrics developing very different typologies; then, from the 1970s, the city developed programmed urban fabrics to the east of the city center, and other unplanned fabrics to the west.

From 2004-2017, once its natural location was saturated, the city expanded to the far northeast, then towards the northwestern side, through the sand dunes ring; the formatting operations (utilities, road network, potable water...) in these areas are inexpensive compared to rough or steep areas (Hadjab et al., 2012), at which time the built-up area increased from $10.08 \mathrm{~km}^{2}$ in 2004 to $10.18 \mathrm{~km}^{2}$ in 2007 , it reached to $10.51 \mathrm{~km} 2$ in 2017 (RBA, 2017), (Figure 4).

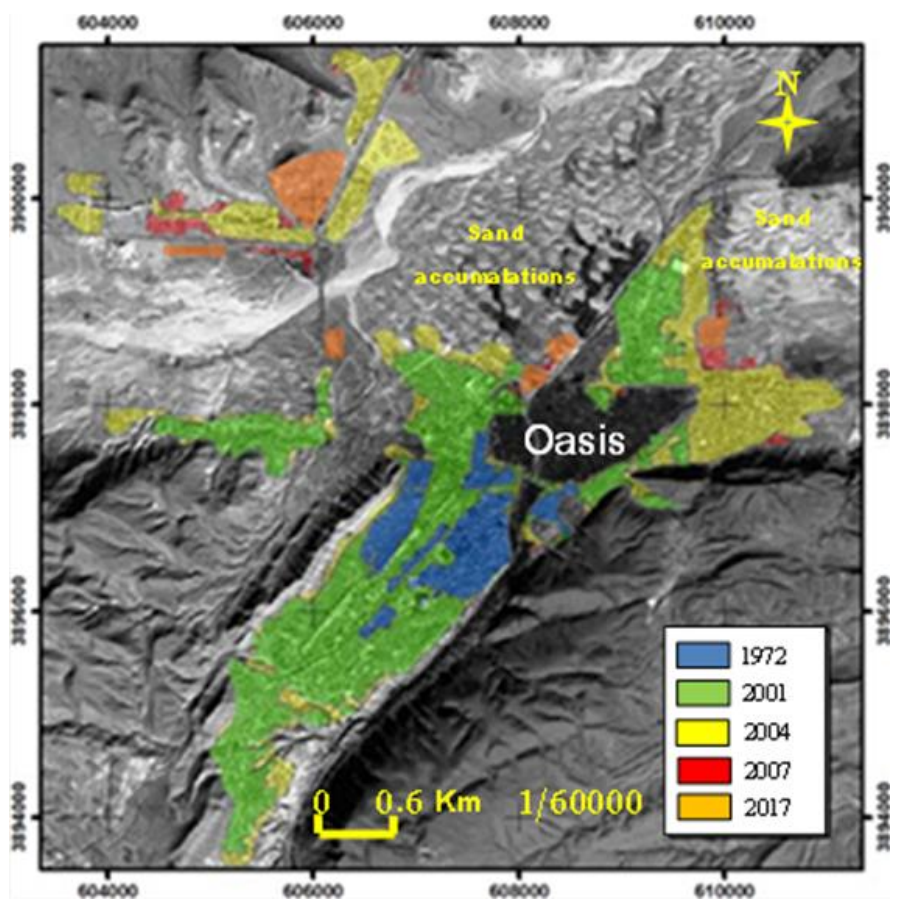

Figure 4. The urban expansion of Boussaâda city (Source: Salmon et al., 2009; and authors processing)

\section{Factors influencing the urban expansion of the city towards the outskirts}

\section{- Natural factors}

The expansion of the city is proceeding according to the imperative of the natural obstacles that control its direction. Natural geographical conditions are the basis of urban expansion (Tong et al., 2018).

The development of the urban fabric of the city of Boussaâda has a general direction in the north, governed by the mountain heights represented by the mountain of "Kerdada" in the east and the mountain of "Izzaddin" in the west, as well as the agricultural lands (Oasis of Palms) located in the northeast, the woods in the northwestern part of the city, and the sand dunes to the north. These natural elements 
permeate a dense hydrographic network, most notably the valley of "Maytar" and the valley of Boussaâda, which divides the city into two parts, east and west (Berbache, 2008), (Figure 5). All these natural barriers greatly affected the city's urbanization process.

\section{- Population growth and immigration factors}

The city of Boussaâda witnessed rapid demographic growth, and rural immigration. The city of Boussaâda was rapidly growing in 196677, when the population increased from 24244 in 1966 to 50800 people in 1977 (6.1\% growth rate), which doubled the population in 10 years with an amount of 26556 people because of the local immigration.

The number of immigrants according to the official census for the period 1966-1977 was 9661 immigrants at the rate of 878 immigrants annually (ONS, 1966-1977). This indicates that the city is an attractive region for the population, due to its tourist importance, its location on the one hand, and also its arrangement in the urban network of the province, where we find it occupying the second place, in addition to its availability on various installations and necessities of life. The rural migration to the city of Boussaâda had a percentage of $63.4 \%$ of total arrivals during the period 1987-1998 (ONS, 1987-1998), this explains the poor living conditions in these areas with the low level of health and educational services, which compels them to migrate, especially the rural areas, which led to the migration of its residents towards the city in search of security, stability and a better life. The continuity of the migration movement towards the city of Boussaâda is also evidenced by the increase in the population during the period 2008-2017, where the city's population moved from 125553 in 2008 to 157476 in 2017 (2.87\% growth rate) (DPSB, 2017).

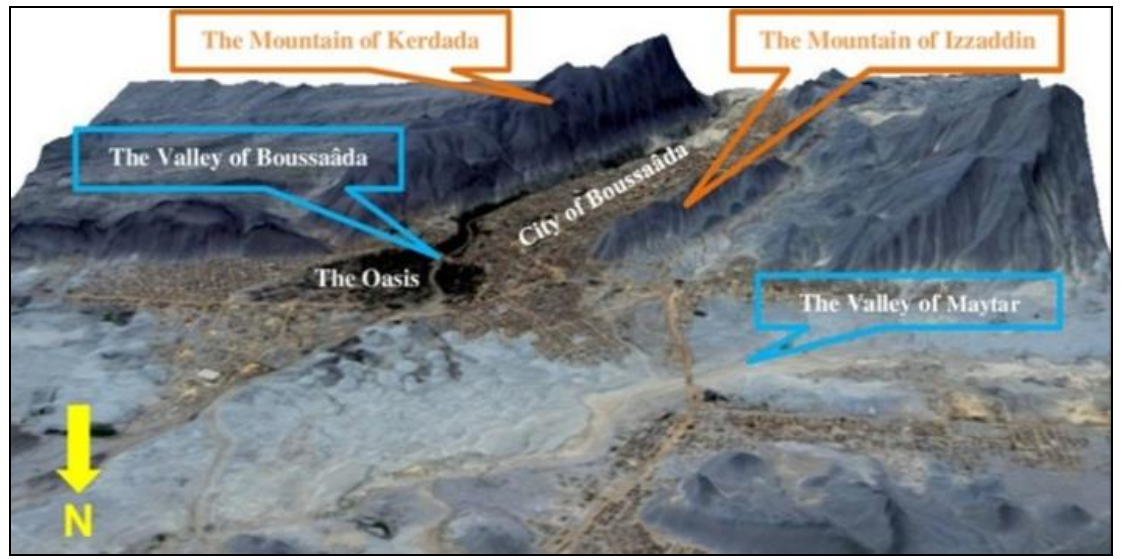

Figure 5. Three dimension view of the oasis of Boussaâda (Source: https://earthexplorer.usgs.gov and authors processing)

Several researchers noted that there was significant correlation between the total population and the built-up area (Tong et al., 2018), which indicated that population growth was one of the main driving factors of urban expansion, so many residents of the neighboring municipalities moved to the city, resulting in its expansion into suburbs surrounding the city, we mention specifically at the expense of the oasis.

\section{RESULTS AND DISCUSSION}

\section{Structural changes in the architectural heritage of the oasis}

The cultural heritage of the oasis is the nature of traditional housing, which symbolizes a society adapted by simple means to cli matic and natural data. However, with the random urban expansion, some buildings were subjected to changes and transformations by their residents, as many residents began to demolish their homes and were replaced by modern residential buildings, while housing that preserved the original local character has experienced changes in the internal structure, or at the level of facades.

\section{The degradation and loss of agricultural land of the oasis}

A number of studies (López et al., 2001; Grigorescu and Kucsicsa, 2017; Ahmad and Laxmi, 2016; Lasisi et al., 2017) have shown the effect of uncontrolled and unplanned urbanization, in the form of sprawl, on vegetation and agricultural land-uses, subjecting periurban areas to multiple activities which are mostly informal. Urban dynamics and development also contribute to the extinction or shrinking of farmlands (Lasisi et al., 2017).

The city of Boussaâda, when found on this site, was not expected to reach this large and rapid growth which was at the expense of agricultural land and non-renewable properties. We recall in particular the oasis located on the eastern side of the valley (Figure 8), which is considered as the city's lung, it also plays an effective role, because it is an impenetrable barrier to sand encroachment in to the city (Berbache and Hadjab, 2017), with an exceptional biological diversity, and a system of practical knowledge and practices that humans have created for the sustainable management of adaptation and climate change, making it an area of integrated development throughout the ages. It is also a barrier to dust-laden winds due to its large area which is estimated at 250 hectares during the years 1850-1860 (DSA, 2017). Two types of agriculture are practiced in the oasis: continuous palm growing and vegetable and fruit cultivation (Berbache, 2008), (Table 1).

Table 1. The area of the oasis and the number of palms change compared to the number of dwellings (Data source: DSA, 2017)

\begin{tabular}{|c|c|c|c|}
\hline The years & The area of the oasis (hectare) & Number of palms & Number of dwellings \\
\hline $\mathbf{2 0 0 4}$ & 155 & 10,000 & 268 \\
\hline $\mathbf{2 0 1 7}$ & 100 & 6,000 & 500 \\
\hline
\end{tabular}

Table 1 show the oasis contained 25,000 palm trees and 500 orchards, between the years 1850 and 1860, but this number dropped to 10,000 palm in 2004, and to 6,000 palms in 2017 (DSA, 2017), and palm trees area fell from 155 hectares to 110 hectares in 2005 (Guettouchi et al., 2015), to reach 100hectares in 2017 (DSA, 2017), and the area of agricultural land decreased by 50\%, where every 08 palms per 10 inhabitants (Nacib, 1986), and today it became 10 palms for every 50 inhabitants, where the number of houses reached 268 dwellings in 2002, and then to more than 500 homes in 2017 (DPSB, 2017), and the oasis now represents $1 / 4$ of the city's area, after it was two-thirds of the city's area during the years 1850-1860 (Belouadeh, 2011), (Figure 6). 
Through the (Figure 6), we note an increase in the number of random housing, in contrast, we note a decrease in the density of palm trees in the palm grove and a decrease in oasis lands.

Factors contributing to the invasion of the urban expansion of the oasis

- Influence of laws and legislations for preserving tourist heritage and agricultural lands

Although there are several laws promulgated by the Algerian legislator that emphasize the protection and rehabilitating the architectural heritage and the protection of agriculture land and prevent them from being converted to urban land, foremost of which is the cultural heritage law (98-04), the Real Estate Directive law (90-25) and the Development and Reconstruction Law (90-29), but the field incarnation of these laws is very weak with the absence of deterrence devices for violators of these texts.

This rapid urban dynamics with the lack of a clear plan for urban management resulted in an irrational expansion of the urban environment through the extension at the expense of the Oasis.

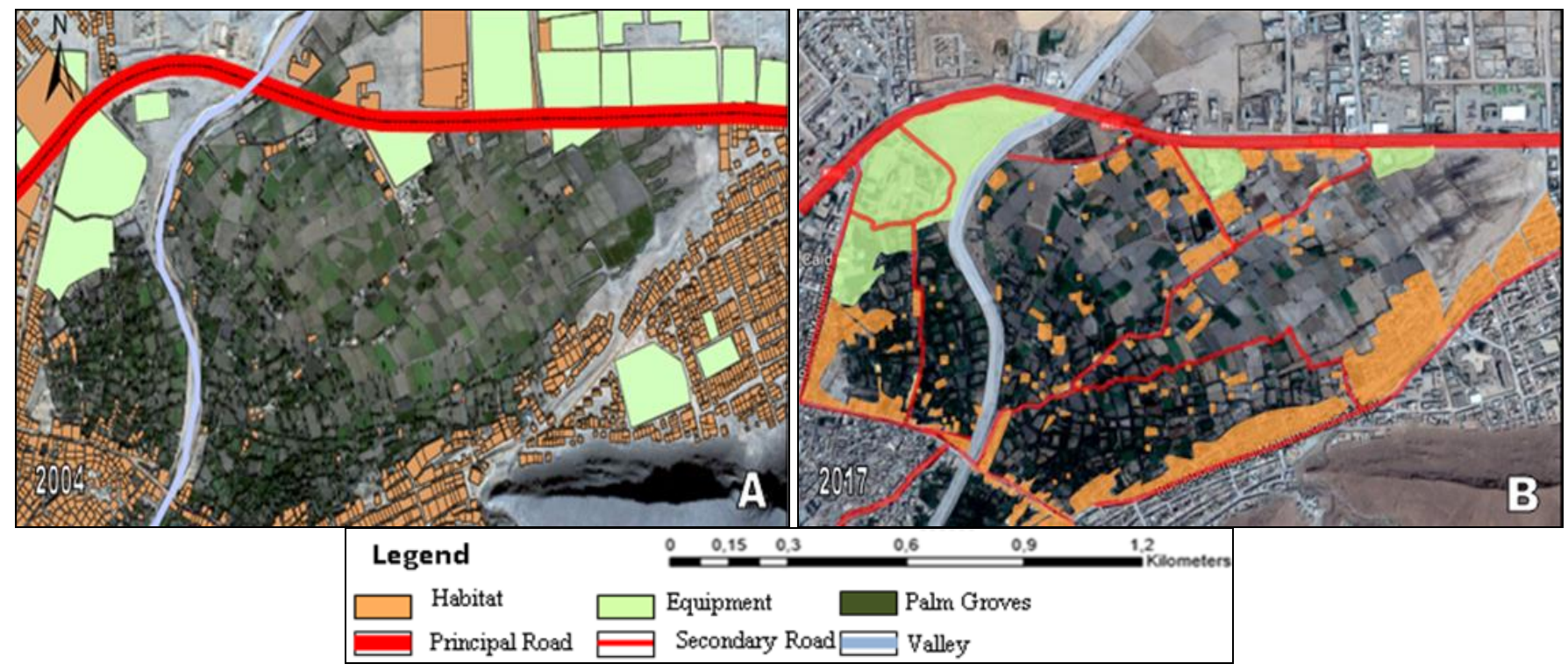

Figure 6. The random habitation invasion of the oasis and the decrement of its lands between 2004 and 2017 (Sources: provided by Google Earth images (A, 2004-B, 2017) and authors processing).

\section{- Influence of government planning and policy}

Governmental actions and intentions that regarding urban expansion also have decisive influences on the socio-economic development (Tong et al., 2018).

- The oasis was provided with the construction of some equipment with an area of 6.3542 hectares, distributed as follows (Table 2).

Table 2. Types of equipment inside the oasis (data source: RBA, 2017)

\begin{tabular}{|c|c|}
\hline Equipment type & The area (hectares) \\
\hline Tourist & 4.57 \\
\hline Mosque & 0.05 \\
\hline Educational & 1.625 \\
\hline Security & 0.1092 \\
\hline Total & $\mathbf{6 . 3 5 4 2}$ \\
\hline
\end{tabular}

- The oasis benefited from the technical networks like the electricity network in 1981.

- The oasis benefited also of the natural gas and drainage channels throw networks in the period (2006-2007).

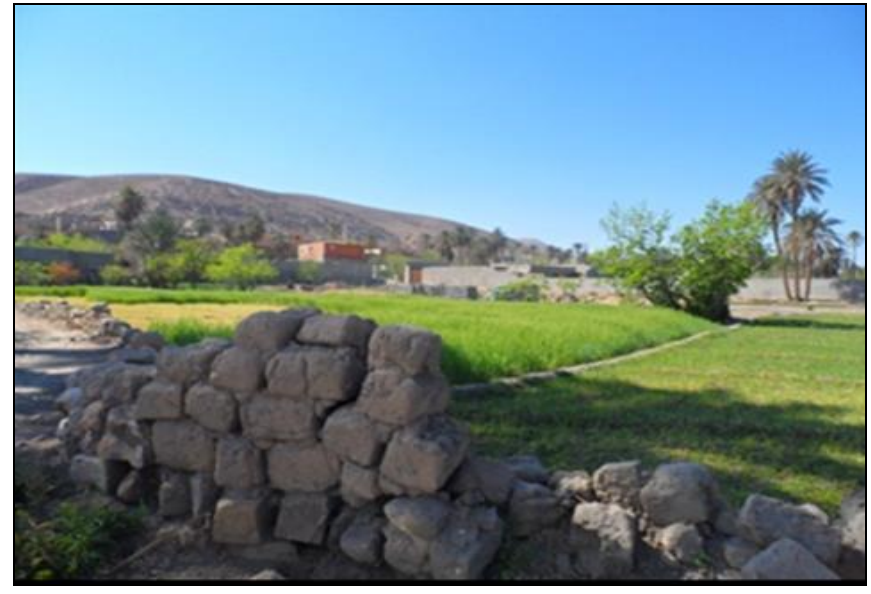

Figure 7. The urban Expansion on the expanse of the oasis

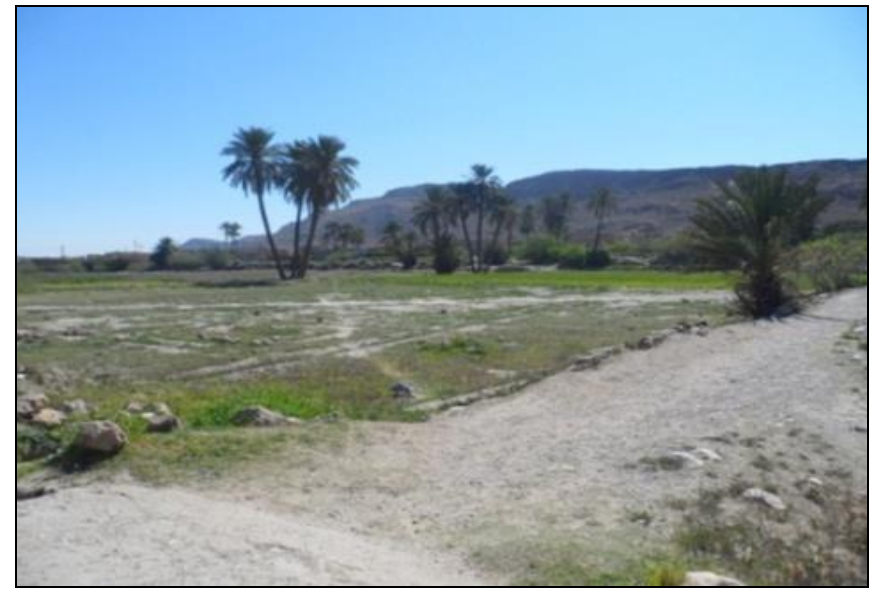

Figure 8. Abandoned and degraded gardens in the palm groves 
The establishment of some necessary facilities and services by the state, and the construction of roads in the vicinity and inside the oasis, made it easier for citizens to build there. Recently, several studies have explored that there is an important relationship between vehicular roads and urbanization (Xie et al., 2016). However, the vehicular roads construction in oasis of Boussaâda is still unknown.

All these factors combined led to a partial destruction of the oasis (Nouibat et al., 2014), Figure 7, Figure 8.

\section{CONCLUSION AND RECOMMENDATIONS}

Our study showed that the Oasis of Boussaâda witnessed a rapid urban expansion that led to the consumption of its urban area, as this expansion has governed factors, which are the natural factors that made the city's expansion towards the north and the population and migration factors (local and rural) as large numbers of population have moved to the urban area, attracted by the importance of the city Tourist, education, employment, health care, and other public resources available in the city center, and given the saturation of the urban fabric of the city, the residents were forced to reside on its outskirts in a random manner, which led to: Structural changes in the architectural heritage of the oasis and the degradation and loss of agricultural land of the oasis, and factors including: influence of laws and legislations for preserving tourist heritage and agricultural lands, influence of government planning and policy, the nature of the real estate ownership of the oasis.

Through the results of the study, we have suggested a series of recommendation are as follows:

* Forming committees for monitoring and preserving agricultural lands from the phenomenon of urban expansion.

* The necessity of coordination between the concerned authorities in order to put an end to the phenomenon of urban expansion on the agricultural lands in the oasis.

* Determine the urban expansion trends of the city in a studied and sound manner.

* Urban planning and policies have a direct influence on urban expansion, so the planning and policies must be based on the environmental, economic, and population factors in order to guarantee sustainability of the oases.

* With regard to the scale of the intervention, this must take into account the development of tourist ass ets throughout the region the example: (1) of the valley of Boussaâda which constitutes an exceptional geo-site to protect and enhance by creating a geological path, in order to have a tourist route around the Moulin Ferrero, the palm grove and the valley; (2) Paying attention to the architectural heritage within the oasis by restoring the old buildings in order to exploit them on the tourist side.

* The development of a sustainable tourism policy through the restoration, preservation and integration of existing heritage on the one hand, and on the other, the encouragement of foreigners and locals to invest.

\section{REFERENCES}

Adjewodah, P., \& Beier, P. (2004). Working with traditional authorities to conserve nature in West Africa. African Conservation Telegraph, 1(2), 3-5.

Ahmad, F., \& Goparaju, L. (2016). Analysis of urban sprawl dynamics using geospatial technology in Ranchi City, Jharkhand, India. Journal of Environmental Geography, 9(1-2), 7-13. https://doi.org/10.1515/jengeo-2016-0002

Azhayev, G., Esimova, D., Sonko, S.M., Safarov, R., Shomanova, Zh., \& Sambou, A. (2020). Geoecological environmental evaluation of Pavlodar region of the Republic of Kazakhstan as a factor of perspectives for touristic activity. GeoJournal of Tourism and Geosites, 28 (1), 104-113. https://doi.org/ $10.30892 /$ gtg. $28108-455$

Bai, J., Chen, X., Li, L., Luo, G., \& Yu, Q. (2014). Quantifying the contributions of agricultural oasis expansion, management practices and climate change to net primary production and evapotranspiration in croplands in arid northwest China. Journal of arid environments, 100, 31-41. https://doi.org/10. 1016/j.jaridenv.2013.10.004

Barnes, K.B., Morgan III, J.M., Roberge, M.C., \& Lowe, S. (2001). Sprawl development: Its patterns consequences, and measurement. Towson University, Towson, 1-24.

Belouadeh, N. (2011). Développement Urbain et Préservation du Patrimoine Architectural dans les Médinas Cas de la Médina de Boussaâda [Urban development and preservation of architectural heritage in the medinas Case of the medina of Boussaâda], Thesis of magister, Mohamed Khider University, Bisra, Algeria.

Berbache, H. (2005). Les modèles de reconstruction dans l'oasis de Boussaâda [The models of reconstruction in the Oasis of Boussaâda], Engineer's degree in the Geography, University of Science and Technology Houari Boumediene, Algiers Algeria.

Berbache, H. (2008). Croissance urbaine et défis de l'environnement: Cas de la Commune de Boussaâda [Urban growth and environmental challenges: Case of the Commun of Boussaâda], Thesis of magister, University of Science and Technology Houari Boumediene, Algiers, Algeria.

Berbache, H., \& Hadjab, M. (2017). The impact of sand encroachment phenomenon on urbanisation: case of the commun of Boussaâda, Algeria. Arab Geographical Journal, 70, 291-313.

Eshun, G., \& Tichaawa, T.M. (2020). Community participation, risk management and ecotourism sustainability issues in Ghana. GeoJournal of Tourism and Geosites, 28(1), 313-331. https://doi.org/10.30892/gtg.28125-472

Grigorescu, I., \& Kucsicsa, G. (2017). Spatial and temporal dynamics of urban sprawl in the Romanian Plain over the last century. Romanian Journal of Geography, 61(2), 109-123.

Guettouchi, A., Chrif, K., Belguedj, M., Abdelkrim, F., Kadri, H., Belkadi, F.Z., Mahdi, M., Soltani, H., Chaabi, Z., \& Ykhlef, N. (2015). Inventaire et conservation de la palmeraie de Boussaâda, Algérie [Inventory and conservation of the palm grove of Boussaâda, Algeria]. National Institute of Agronomic Research of Algeria. Agronomic research, 27, 48-56 (in french).

Hadjab M., Khalfallah B., \& Redjem A. (2012). L'urbanisation d'une ville oasienne «Boussaâda» face aux risques d'inondations et d'ensablement [Urbanization of Oasian City «Boussaâda» Faced with the Risk of Flood and Siltation], Annals of University of Bucharest, University of Bucharest, Bucharest, Romania.

Ilieş, D.C., Baias, Ş., Buhaş, R., Ilieş, A., Herman, G.V., Gaceu, O., Dumbravă, R., \& Măduţa, F.M. (2017). Environmental education in protected areas. Case study from Bihor County, Romania. Geojournal of Tourism and Geosites, 19(1), 126-132.

Jia, B., Zhang, Z., Ci, L., Ren, Y., Pan, B., \& Zhang, Z. (2004). Oasis land-use dynamics and its influence on the oasis environment in Xinjiang, China. Journal of Arid Environments, 56(1), 11-26. https://doi.org/10.1016/S0140-1963(03)00002-8

Kherrour, L., Rezzaz, M.A., \& Hattab, S. (2018). Rehabilitaion of geographical areas for a tourist development the case of Batna Region's Mountain (Algeria). GeoJournal of Tourism and Geosites, 22 (2), 455-469. https://doi.org/10.30892/gtg.22215-302

Kouran, M. (2015). L'impact environnemental d'une expansion aléatoire au détriment des espaces verts: Cas de la ville de Boussaâda [The environmental impact of random expansion at the expense of the green areas: Case of the city of Boussaâda]. Thesis of Magister, Mohamed Boudiaf University, M'sila, Algeria.

Lasisi, M., Popoola, A., Adediji, A., Adedeji, O., \& Babalola, K. (2017). City expansion and agricultural land loss within the peri-urban area of Osun State, Nigeria. Ghana Journal of Geography, 9(3), 132-163.

Lettre Wallonie-Bruxelles à Alger $\mathrm{N}^{\circ} 1$. (2008- 2010). Coopération Universitaire, Etude Environnementales et Aménagement des Zones Oasiennes en Algérie: Cas des Oasis de Laghouat et de Boussaâda [University Cooperation, Environmental Studies and Development of Oasis Areas in Algeria: Case of the Oases of Laghouat and Boussaâda], Algiers, Algeria. 
Liu, Y., Xue, J., Gui, D., Lei, J., Sun, H., Lv, G., \& Zhang, Z. (2018). Agricultural oasis expansion and its impact on oasis landscape patterns in the southern margin of Tarim Basin, Northwest China. Sustainability, 10(6), 1957. https://doi.org/10.3390/su10061957

López, T., Aide, T.M., \& Thomlinson, J.R. (2001). Urban expansion and the loss of prime agricultural lands in Puerto Rico. Ambio: a Journal of the Human environment, 30(1), 49-54. https://doi.org/10.1579/0044-7447-30.1.49

Luo, G.P., Zhou, C.H., Chen, X., \& Li, Y. (2008). A methodology of characterizing status and trend of land changes in oases: A case study of Sangong River watershed, Xinjiang, China. Journal of Environmental Management, 88(4), 775-783. https://doi.org/10.1016/j.jenvman.2007.04.003

Maeda, E.E., Pellikka, P.K., Clark, B.J., \& Siljander, M. (2011). Prospective changes in irrigation water requirements caused by agricultural expansion and climate changes in the eastern arc mountains of Kenya. Journal of Environmental Management, 92(3), 982-993. https://doi.org/10.1016/j.jenvman.2010.11.005

Nacib, Y. (1986). Cultures Oasiennes: Boussaâda [Oasis cultures: Boussaâda]. Essai d'histoire social, ENAL, Alger, Algérie.

Nian, Y., Li, X., Zhou, J., \& Hu, X. (2014). Impact of land use change on water resource allocation in the middle reaches of the Heihe River Basin in northwestern China. Journal of Arid Land, 6(3), 273-286. https://doi.org/10.1007/s40333-013-0209-4

Nouibat, B., Redjem, A., \& Grecu, F. (2014). Analysis of natural nazards in urban areas: The city of Boussaâda as a case study in Algeria. Revista de geomorfologie, 16, 89-98.

Qi, S.Z., Li, X.Y., \& Duan, H.P. (2007). Oasis land-use change and its environmental impact in Jinta Oasis, arid northwestern China. Environmental monitoring and assessment, 134(1-3), 313. https://doi.org/10.1007/s10661-007-9622-5

Salmon, M., Ammiche, A., Guermit, A., Redjem, A. \& Oser, A. (2009). Boussaâda: une ville touristique confrontée au développement urbain, Apport de la télédétection. [Boussâ̂da: a tourist town confronted with urban development, Contribution of remote sensing]. Scientific animation day (JAS09) of the AUF, Algiers, Algeria.

Tong, H., Shi, P., Zhu, G., Pearson, A., Li, Q., Liu, Y., \& Liu, H. (2018). The characteristics of oasis urban expansion and drive mechanism analysis: A case study on Ganzhou District in Hexi Corridor, China. Sciences in Cold and Arid Regions, 7(3), 282-292. https://doi.org/10.3724/SP.J.1226.2015.00282.

Torrens, P.M., \& Alberti, M. (2000). Measuring sprawl. Working paper no. 27, Centre for Advanced Spatial Analysis, University College, London.

Wahdan, G. (2013). Directions of Urban Expansion And its Impacts on Agricultural Landsin Tubas District. Thesis of Magister, Najah National University, Nablus Palestine.

Wang, G., Shen, Y., Zhang, J., Wang, S., \& Mao, W. (2010). The effects of human activities on oasis climate and hydrologic en vironment in the Aksu River Basin, Xinjiang, China. Environmental Earth Sciences, 59(8), 1759-1769. https://doi.org/10.1007/s12665-009-0158-6

Xie, Y., Gong, J., Sun, P., \& Gou, X. (2014). Oasis dynamics change and its influence on landscape pattern on Jinta oasis in arid China from 1963a to 2010a: Integration of multi-source satellite images. International Journal of applied earth observation and geoinformation, 33, 181-191. https://doi.org/10. 1016/j.jag.2014.05.008

Zhou, D., Wang, X., \& Shi, M. (2017). Human driving forces of oasis expansion in northwestern China during the last decade- a case study of the Heihe River basin. Land Degradation \& Development, 28(2), 412-420. https://doi.org/10.1002/ldr.2563

Zuo, L., Zhang, Z., Zhao, X., Wang, X., Wu, W., Yi, L., \& Liu, F. (2014). Multitemporal analysis of cropland transition in a climate-sensitive area: A case study of the arid and semiarid region of northwest China. Regional environmental change, 14(1), 75-89. https://doi.org/10.1007/s10113-013-0435-5

*** DPSB. (2017). Planning and Budget Monitoring Department. M'sila, Algeria.

*** DSA. (2017). Department of Agricultural Services. Boussaâda, Algeria.

*** ONS. (1966, 1977, 1987, 1998, 2008). National Statistics Office. M'sila, Algeria.

*** RBA. (2001, 2008, 2017). Reconstruction and Building Authority. Boussaâda, Algeria.

https://earthexplorer.usgs.gov (retrieved on 22.09.2019).

https://www.google.com/maps/ (retrieved on 2004 and 15.11.2017).

Article history:

Received: 08.06.2020
Revised: 24.07.2020
Accepted: 31.08 .2020

Available online: 21.09 .2020 